\title{
Lithostratigraphy of the Siwalik Group, Khutia Khola section, Far Western Nepal Himalaya
}

\author{
Swostik Kumar Adhikari ${ }^{1,2 *}$ and Tetsuya Sakai ${ }^{1}$ \\ ${ }^{1}$ Department of Geoscience, Shimane University, Matsue 690-8504, Japan \\ ${ }^{2}$ Department of Geology, Tri-Chandra Campus, Tribhuvan University, Ghantaghar, Kathmandu, Nepal \\ *Email:swostik_adhikari@hotmail.com
}

\begin{abstract}
The Neogene fluival sediments (Siwalik Group) forming the southernmost hills in the Himalaya is well exposed along the Khutia Khola in the Far Western Nepal. The newly established lithostratigraphy is subdivided into the Jagati Formation ( 2110 m, equivalent to the Lower Siwalik) and the Kala Formation (2050 m, equivalent to the Middle Siwalik) in ascending order. Each formation is further divided into three members; the lower, middle and upper, based on the ratio of mudstone vs. sandstone beds as well as color and grain size of sandstone. The Jagati Formation is characterized by reddish-brown mudstones interbedded with very fine- to coarse-grained sandstones. Paleosols characterized with burrows, rhizoliths, desiccation cracks, concretions and nodules are present in higher proportion than thinly laminated or massive mudstone beds. The Kala Formation comprises thin- to thick-bedded, very fine- to very coarse-grained sandstones and pebbly sandstones interbedded with reddishbrown, greenish-grey to dark-grey mudstones. Sandstone beds exhibit "salt and pepper" appearance. In the lower part of the upper member sub-rounded to rounded pebbles are scattered along with trough and planar cross-laminations in sandstone beds, whereas the gravel size tends to be larger and few cobble size gravels also appear in the upper part. Thinly laminated or massive mudstones are common and paleosols are less frequent. The age of the boundary between the Jagati and Kala Formations (Lower-Middle Siwaliks) is around 11.05 Ma. The boundaries age between the middle and upper members of the Jagati Formation is around 12.7 Ma and between the lower and middle members of the Kala Formation is around 9.0 Ma. The dominance of finer sediments and thinner sandstone units than that of neighboring Siwalik successions indicate the fluvial facies of the Khutia Khola section is deposited by a small river system and may represent the interfluve setting of major river systems.
\end{abstract}

Keywords: Lithostratigraphy, correlation, Khutia Khola, Siwalik Group, Far Western Nepal

Received: March 14, 2015

Revision accepted: June 5, 2015

\section{INTRODUCTION}

This study focuses on the lithostratigraphy of the Siwalik Group exposed along the Khutia Khola, Far Western Nepal. The Siwalik Group, known as the molassic sediments exposed in association with Himalayan uplift, was deposited during the middle Miocene to the early Pleistocene as a $4-6$ $\mathrm{km}$ thick fluvial sediments at the southern front of the entire Himalayan belt (Gansser 1964, Prakash et al. 1980, Tokuoka et al. 1986, Quade et al. 1995, Dhital et al. 1995, Burbank et al. 1996, DeCelles et al. 1998, Corvinus and Rimal 2001). The Siwalik Group has been traditionally classified as three units (Lower, Middle and Upper Siwaliks) (Auden 1935, Hagen 1969, Yoshida and Arita 1982, Quade et al. 1995, DeCelles et al. 1998, Gautam and Fujiwara 2000, Ojha et al. 2000, Robinson et al. 2006, Sharma et al. 2007) and with locally two, four- or five- fold units is acceptable (Glennie and Ziegler 1964, Sharma 1973, Tokuoka et al. 1986, 1988; Sah et al. 1994, Corvinus and Nanda 1994, Dhital et al. 1995, Ulak and Nakayama 1998, Sigdel et al. 2011). The common three-fold classification starts in general with the mudstone-dominated Lower Siwalik, grading upward into the sandstone-dominated Middle Siwalik and the Upper Siwalik of the conglomerate- dominated sediments (Medlicott 1875, Pilgrim 1913, Wadia 1957, Auden 1935, Hagen 1969, Yoshida and Arita 1982, Quade et al. 1995, DeCelles et al. 1998, Upreti 1999, Gautam and Fujiwara 2000, Ojha et al. 2000, Robinson et al. 2006). The age of the Siwalik Group in the Nepal Himalaya ranges from 16 to $1 \mathrm{Ma}$, based on paleomagnetic studies (Tokuoka et al. 1986, Harrison et al. 1993, Appel and Rosler 1994, Gautam and Appel 1994, Rosler et al. 1997, Gautam and Fujiwara 2000, Ojha et al. 2000).

The Siwalik Group along the Khutia Khola was also classified based on the classical tripartite classification (Lower, Middle and Upper Siwaliks) (Ojha et al. 2000, Sharma et al. 2007). Ojha et al. (2000) made broad-scale description of lithology as well as the paleomagnetic polarity of the Siwalik Group sediments. The lithological data shown in Ojha et al. (2000) indicate the muddier sediment succession in the Khutia Khola section than in other Siwalik successions (cf. Tokuoka et al. 1986, 1988; Sah et al. 1994, Corvinus and Nanda 1994, Dhital et al. 1995, Ulak and Nakayama 1998, Sigdel et al. 2011). This succession is important for understanding of the Himalayan Uplift and climatic changes as well as environmental changes in the following points: (1) The muddy Siwalik succession 


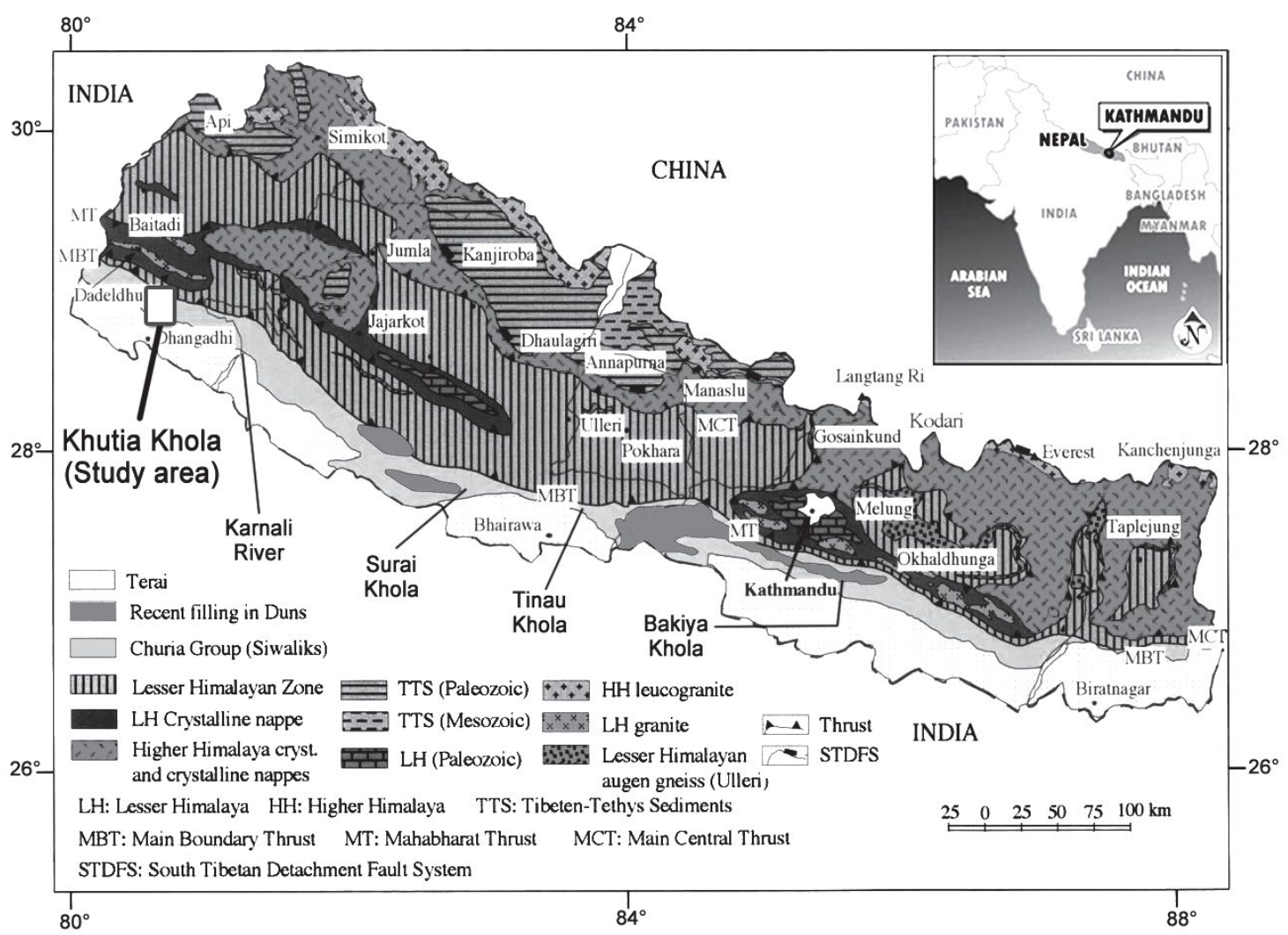

Fig. 1 : Location map of the study area. The Khutia Khola area is indicated in Box. (modified from Upreti and Le Fort 1999).

could be a better archive than the sand-dominated Siwalik succession because the loss of sediment succession by stream erosion could be smaller than the sand-dominated cases, and (2) the sediments may provide a good example of interfluve environments of the Siwalik phase. Previous studies dealt stratigraphy of the Khutia Khola section (Quade et al. 1995, DeCelles et al. 1998, Ojha et al. 2000, Sharma et al. 2007), however their lithological information is limited. The present study proposes the lithostratigraphic classification based on the results of the high-resolution description of the Siwalik sediments along the Khutia Khola and its tributaries.

\section{GEOLOGICAL SETTING}

The distribution of the Siwalik Group of the Khutia Khola area is marked by the Main Frontal Thrust (MFT) to the south and the Main Boundary Thrust (MBT) to the north. In general the Main Dun Thrust (MDT) or Central Churia Thrust (CCT; Tokuoka et al. 1986) separates the Siwalik Group into the southern and northern belts (DeCelles et al. 1998, Robinson et al. 2006). In the study area, the Jogbudha Thrust (JT) equivalent to MDT/CCT and Rangun Khola Thrust (RKT) separate the Siwalik Group into the southern, central and northern belts (Sharma et al. 2007).

The present study focuses on the rocks cropped out in the southern belt. The strata of the southern belt near the MFT are folded and show complicated geological structures (Fig. 2). The previous stratigraphic studies identified the Lower and Middle Siwaliks (Ojha et al. 2000, Sharma et al. 2007) and time interval ranges from 13.30 to $7.65 \mathrm{Ma}$ according to magnetostratigraphy (Ojha et al. 2000). Around the Khutia Khola area, the Upper Siwalik may be masked by the JT, thrusting the central block onto the southern belt rock from the north.

\section{METHOD}

This study is based on geological traverses carried out along the Khutia river section on the southern belt of the Siwalik Group. The survey of rock units near the MFT were difficult due to thick cover of alluvial fan consisting of a series of terraces. Moreover, the area is covered by dense vegetation. Detailed lithological description has been given in this paper based on the result of bed-by-bed data acquisition of the whole rock exposures along the river section producing a series of columnar sections. Description of lithological characteristics has also been followed by using the Munsell Color Chart (2000).

\section{LITHOSTRATIGRAPY}

Two lithostratigraphic units, the Jagati and Kala Formations in ascending order has been proposed, which are equivalent to the Lower and Middle Siwaliks, respectively. The Upper Siwalik is not exposed in the study area. Each formation is subdivided into the lower, middle and upper members (Fig. 2). 


\section{Jagati Formation}

\section{Type Locality}

The type locality of this formation is around Jagati Village.

\section{Lithology}

This unit is named after Jagati Village, one of the main villages located on the left bank of the Khutia Khola and is well exposed from Hatkholi Village in the south to the Gajari Khola in the north. The Jagati Formation is represented by bioturbated, variegated, reddish-brown, yellowish-brown, brown, yellow, yellowish-grey, grey to greenish-grey mudstones and very fine- to coarse-grained, brown, reddish-grey, light-grey, and grey to greenish-grey sandstones (Fig. 3 and 5). Thickness of the Jagati Formation is about $2110 \mathrm{~m}$. In general, a sandstone unit grades upward into a mudstone unit to form an upwardfining succession. The Jagati Formation is further divided into the lower, middle and upper members based on dominant unit and, color and grain size. The boundary between the lower and middle members is marked by the appearance of interval exhibiting equal proportion of fine- to medium grained, greenish-grey to grey sandstones and variegated to reddishbrown paleosols. The first appearance of greenish-grey to grey

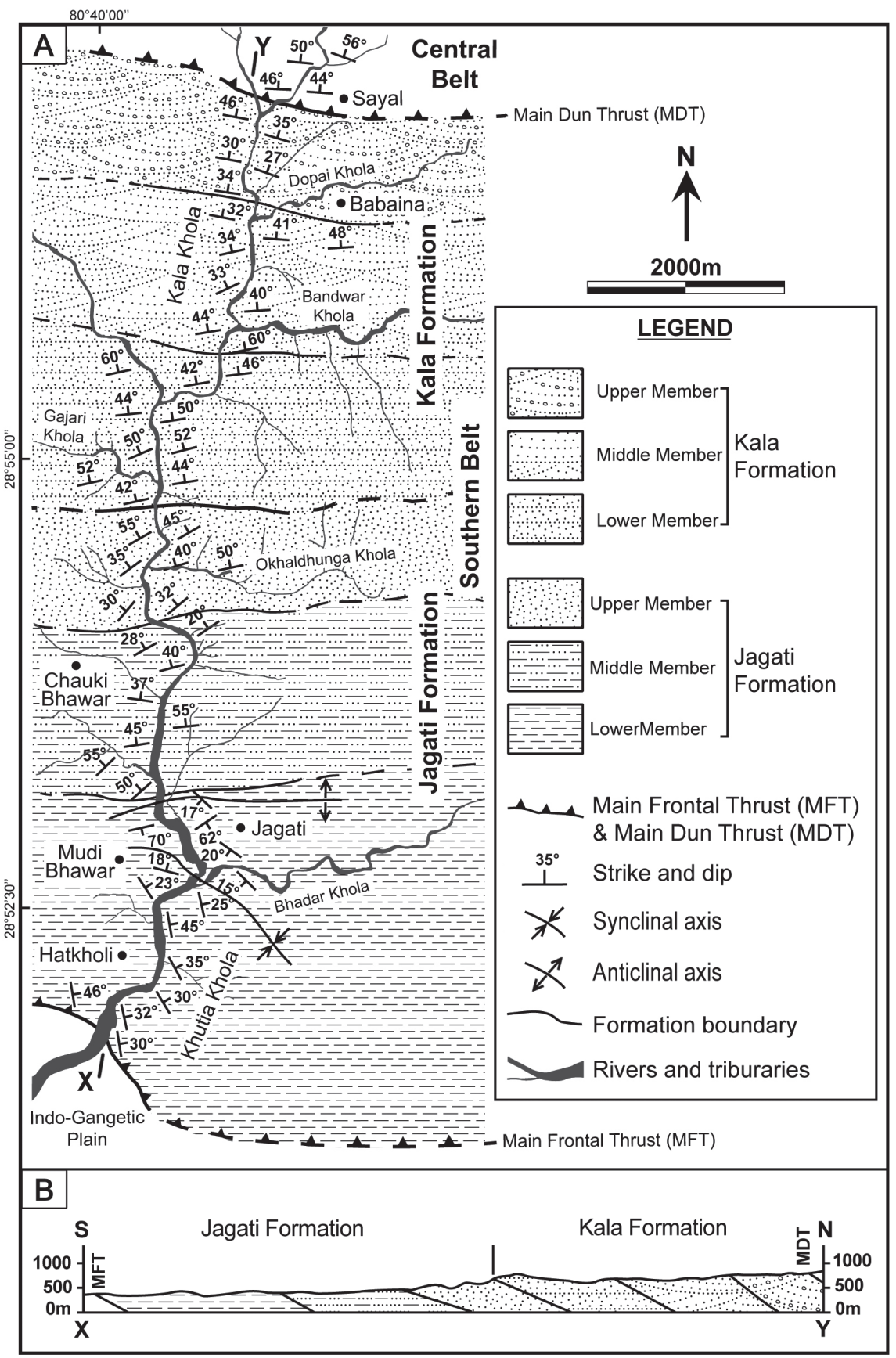

Fig. 2: A) Geological map of the Siwalik Group along the Khutia Khola section and B) Cross-section along X-Y. 
mudstone is marked as the boundary between the middle and upper members.

\section{Lower member}

The lower member is well exposed around Hatkholi and Mudi Bhawar Village. The total thickness of this member is about $860 \mathrm{~m}$. This member is represented by variegated, yellow (10YR 7/6), yellowish-brown (10YR 4/3), brown (7.5YR 5/4) to reddish-brown (2.5YR 3/4, 5YR 4/3) mudstones which are interbedded with very fine- to medium-grained, reddish-grey (2.5YR 6/1), light-grey (GLEY1 7/N, GLEY1 7/10GY, 2.5Y
7/1) to grey (GLEY1 6/N, 10YR 5/1, 5Y 6/1) sandstones (Fig. $3 \mathrm{~A})$. In this member the proportion of mudstones is higher than sandstones (Fig. 5). Thickness of mudstone unit range from 0.2 to $10 \mathrm{~m}$, whereas sandstone units range from 0.3 to $6 \mathrm{~m}$. Some mudstones beds are thinly laminated containing plant fossils, whereas most of the primary structures in mudstones are disturbed by burrows, rhizoliths, desiccation cracks, concretions and nodules, which are typical characteristics of paleosols (Fig. 4A and B). The basal part of the sandstone beds contains parallel or planar cross-laminations and some contain calcareous nodules, and are bioturbated in the upper part. The maximum thickness of fining upward succession is about $15 \mathrm{~m}$.
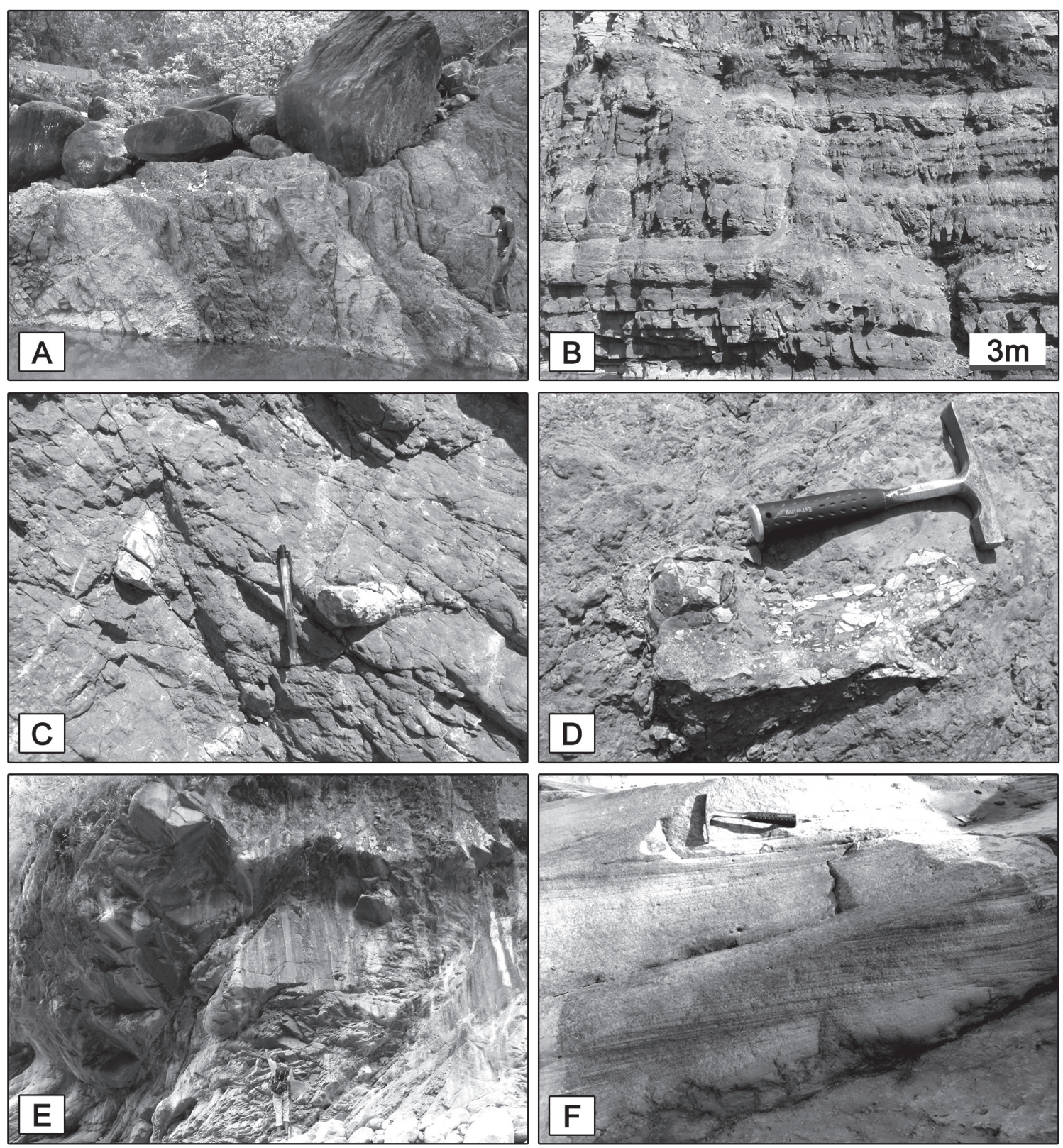

Fig. 3: Outcrop photographs of the Jagati Formation. A) Variegated mudstone alternating with fine-grained sandstone, B) Alternating sandstone and mudstone beds, C) Brown mudstone with bioturbation, rootlets and nodules, D) A vertebrate fossil found in mudstone, E) Very thick bedded sandstone near the boundary of the Jagati and Kala Formations and F) Cross-lamination in sandstone bed. ( $A$ in the lower member. B, C, D in the middle member. E, F in the upper member) 


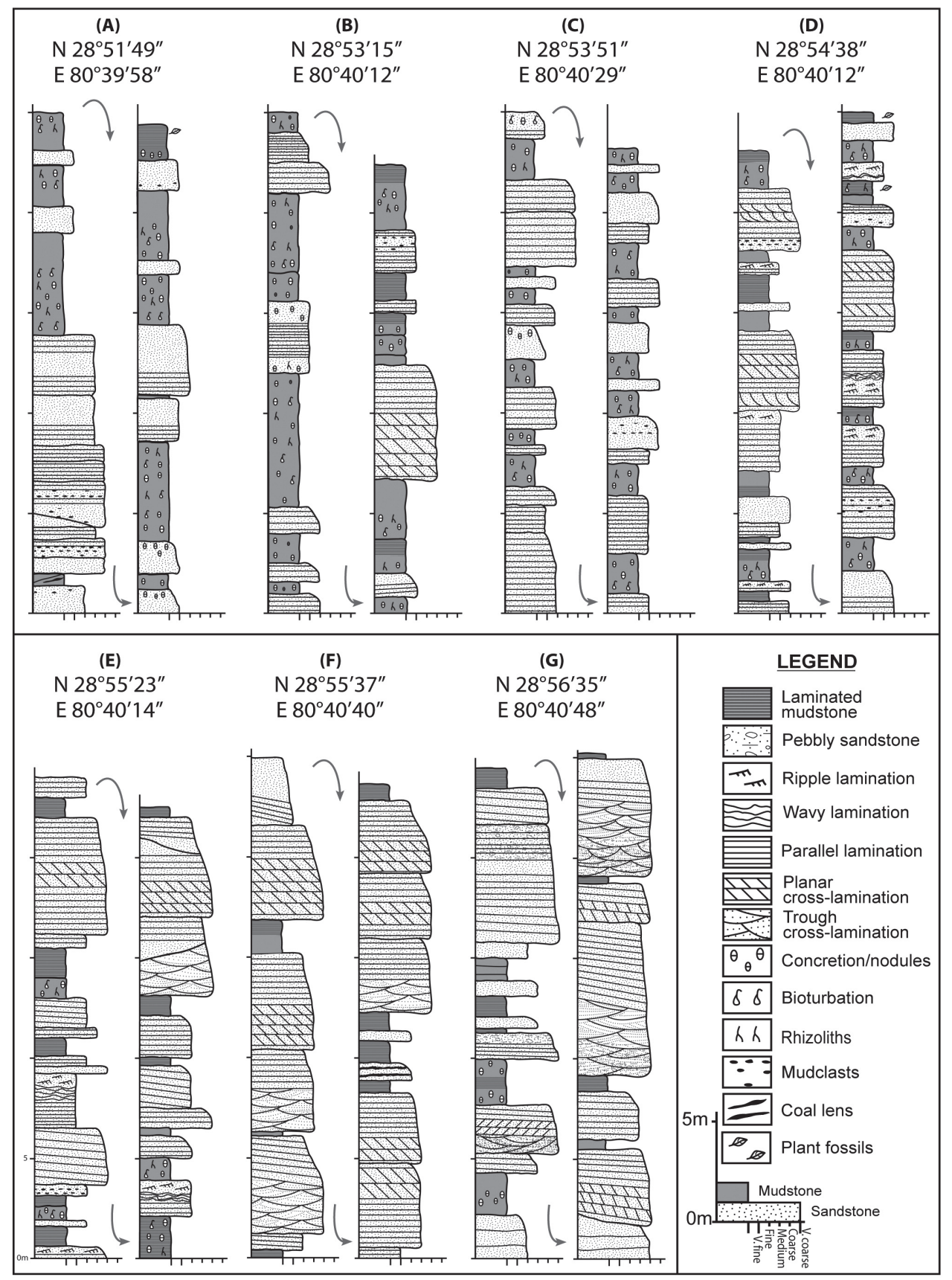

Fig. 4: Typical columnar sections. Jagati Formation (A and B, lower member; C, middle member; and, D upper member). Kala Formation (E, lower member; F, middle member; and, G, upper member).

\section{Middle member}

The middle member is well exposed around Jagati Village and has a total thickness of about $760 \mathrm{~m}$. Fine- to coarse-grained, brown (7.5YR 4/4), light-grey (GLEY1 7/N, GLEY1 7/10GY) to grey (GLEY1 6/N, 10YR 5/1) sandstones and variegated, brown (7.5YR 5/4) to reddish-brown (2.5YR $3 / 4,5 R Y 4 / 3$ ) mudstones characterize this member (Fig. 3B and $4 \mathrm{C})$. The proportion of the mudstones and sandstones is almost equal in this member (Fig. 5). Thickness of mudstone units range from 0.2 to $9 \mathrm{~m}$, whereas sandstone units range from 0.2 to $7 \mathrm{~m}$. Each sandstone tends to be thicker upward in this member. Parallel or planar cross-laminations are preserved in the basal part of the sandstone beds and in some cases mud and sand clasts are scattered in this part. The ripple laminations are also present in some of the upper part of the sandstone beds. The upper part of the sandstone beds is generally bioturbated and some contain calcareous nodules. In the lower part of this member, most of the mudstones show characteristics of paleosols (Fig. 3C) as seen in the lower member and in the upper part thinly laminated mudstones are also present. Vertebrate and plant fossils are preserved in mudstone beds (Fig. 3D). The maximum thickness of finingupward succession is about $16 \mathrm{~m}$. 


\section{Upper member}

The upper member is well exposed around Chauki Bhawar Village and along the Okhaldhunga Khola. Thickness of this member is about $490 \mathrm{~m}$. The very fine- to coarsegrained, light-grey (GLEY1 7/N, GLEY1 7/10GY), grey (GLEY1 6/N, 5Y 6/1, 10YR 5/1) to greenish-grey (GLEY1 $6 / 10 \mathrm{GY}$ ) sandstones and variegated, reddish-brown (5YR $4 / 3)$, brown (7.5YR 5/4), yellowish-grey (5Y 6/2) to greenishgrey (GLEY2 6/5BG) mudstones represent this member (Fig. 4D). The ratio of sandstones is greater than mudstones in this member (Fig. 5). Thickness of sandstone units range from 0.2 to $11 \mathrm{~m}$ (Fig. 3E) and mudstone units range from 0.2 to $6 \mathrm{~m}$. Trough and planar cross-lamination, parallel and ripple laminations are frequently observed in sandstone beds

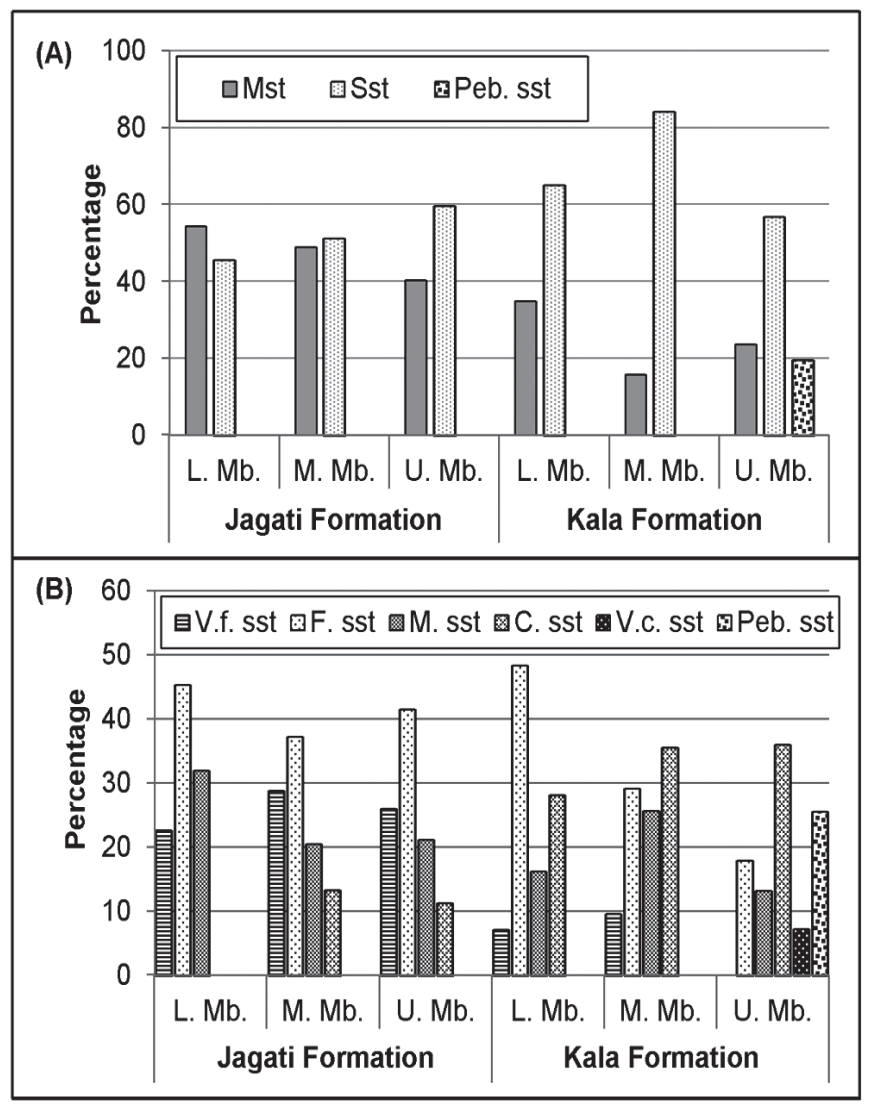

Fig. 5: The distribution of various rocks in the Khutia Khola area. A) Distribution of sandstones, mudstones and pebbly sandstones. B) Distribution of various sandstones. Abbreviation: Mst - mudstone, Sst - sandstone, Peb. sst pebbly sandstone, V.f. sst - very fine grained sandstone, F. sst - fine grained sandstone, M. sst - medium grained sandstone, C. sst - coarse grained sandstone, V.c. sst - very coarse grained sandstone, L. Mb. - lower member, M. Mb. - middle member, U. Mb. - upper member.

(Fig. 3F). The finely laminated, greenish-grey mudstone are frequently occurred, whereas reddish-brown paleosols are less frequent than in the lower and middle members. Some reddishbrown mudstone beds containing bioturbations, rhizoliths, concretion and nodules grade upward into finely laminated greenish-grey mudstone. Molluscan fossils are also found in some finely laminated mudstones. The maximum thickness of fining-upward sequences is about $14 \mathrm{~m}$.

\section{Kala Formation}

\section{Type Locality}

Along Kala Khola, in exposures north of Gajari Khola up to the Sayal Village.

\section{Lithology}

This formation is well exposed from Gajari Khola in the south to Sayal Village in the north. Thickness of the Kala Formation is about $2050 \mathrm{~m}$. This formation is represented by thin- to very thick-bedded, very fine- to very coarse-grained, light-grey, grey to greenish-grey sandstones and pebbly sandstones interbedded with reddish-brown, brown, grey, greenish-grey to dark-grey mudstones (Fig. 5 and 6). Biotite, quartz and feldspar are abundantly present in sandstones showing "salt and pepper" characteristic (e.g. Tokuoka et al. 1988, Dhital et al. 1995). The rock succession of this formation also exhibits fining-upward successions as in the Jagati Formation. This formation is further divided into the lower, middle and upper members. The first appearance of very thickbedded ( $\sim 15 \mathrm{~m})$, medium-to coarse-grained "salt and pepper" sandstones marks the base of the Kala Formation. The first appearance of thick- to very thick-bedded, medium-to very coarse-grained, light-grey to grey sandstones interbedded with grey, greenish-grey massive or finely laminated mudstones marks the boundary between the lower and middle members. The first pebbly sandstone demarks the boundary between the middle and upper member of this formation.

\section{Lower member}

The lower member is well exposed around Gajari Khola and Amthala Village. The total thickness of this member is about $800 \mathrm{~m}$. This member is characterized by presence of medium- to very thick-bedded, very fine- to coarse-grained, light-grey (GLEY1 7/N, 2.5Y 7/1), grey (GLEY1 6/N, 10YR 5/1, 5Y 6/1) to greenish-grey (GLEY2 6/5BG) "salt and pepper" sandstones interbedded with finely laminated greenish-grey (GLEY1 6/10GY, GLEY2 6/5BG) mudstones or bioturbated, variegated, brown (7.5YR 5/4) to reddishbrown (5YR 4/3) mudstones (Fig. 4E). In this member, the proportion of sandstones is higher than mudstones (Fig. 5). Thickness of sandstone units range from 0.3 to $15 \mathrm{~m}$, whereas the thicknesses of mudstone units range from 0.2 to $5 \mathrm{~m}$. The sandstone beds are characterized by trough and planar crosslamination, parallel and ripple laminations (Fig. 6A). The basal parts of some sandstone beds are erosional and, mud and sand clasts are also scattered at the base. Bioturbations as well as concretion and nodules are less frequent in paleosols than those in the Jagati Formation. Some coal lenses (2 to 10 $\mathrm{cm}$ thick) (Fig. 6B) and leaf impressions are also observed in this member. Fining upward succession is clearly seen in thick sandstone beds and the maximum thickness of fining-upward succession is about $17 \mathrm{~m}$. 


\section{Middle member}

The middle member is well exposed between the Bandwar Khola and Dopai Khola, and has a thickness of about $850 \mathrm{~m}$. This member is composed of thick- to very thickbedded, very fine- to coarse-grained, greenish-grey (GLEY1 6/10GY) to grey (GLEY1 6/N, 5Y 6/1, 10YR 5/1) "salt and pepper" sandstones interbedded with thin- to medium-bedded, reddish-brown (5YR 4/3), brown (7.5YR 5/4), yellowishbrown (10YR 7/6) to greenish-grey (GLEY2 6/5BG, GLEY1 6/10GY, GLEY1 4/N) mudstones (Fig. 4F and 6C). Blackcolored mudstones (GLEY1 2.5/N), rich in organic matter, are also interbedded in this member. The proportion of sandstones is higher than mudstones (Fig. 5). Thickness of sandstone units range from 0.5 to $20 \mathrm{~m}$, whereas mudstone units range from 0.2 to $3 \mathrm{~m}$. The sandstone beds are thicker than the lower member and the most part of this member is occupied by the sandstonedominated units. Trough and planar cross-laminations and parallel lamination are commonly observed in thick sandstone beds, representing the lower part of the sandstone units. Mud and sand clasts are scattered within the lower part of some sandstone beds. The greenish-grey mudstones are finely laminated (Fig. 6D), and brown mudstones are massive and contain calcareous concretions and nodules. Some mudstone units are characterized by the lower massive brown mudstone, the overlying finely laminated greenish-grey mudstone and the upper black mudstone. The maximum thickness of finingupward sequences is about $25 \mathrm{~m}$.
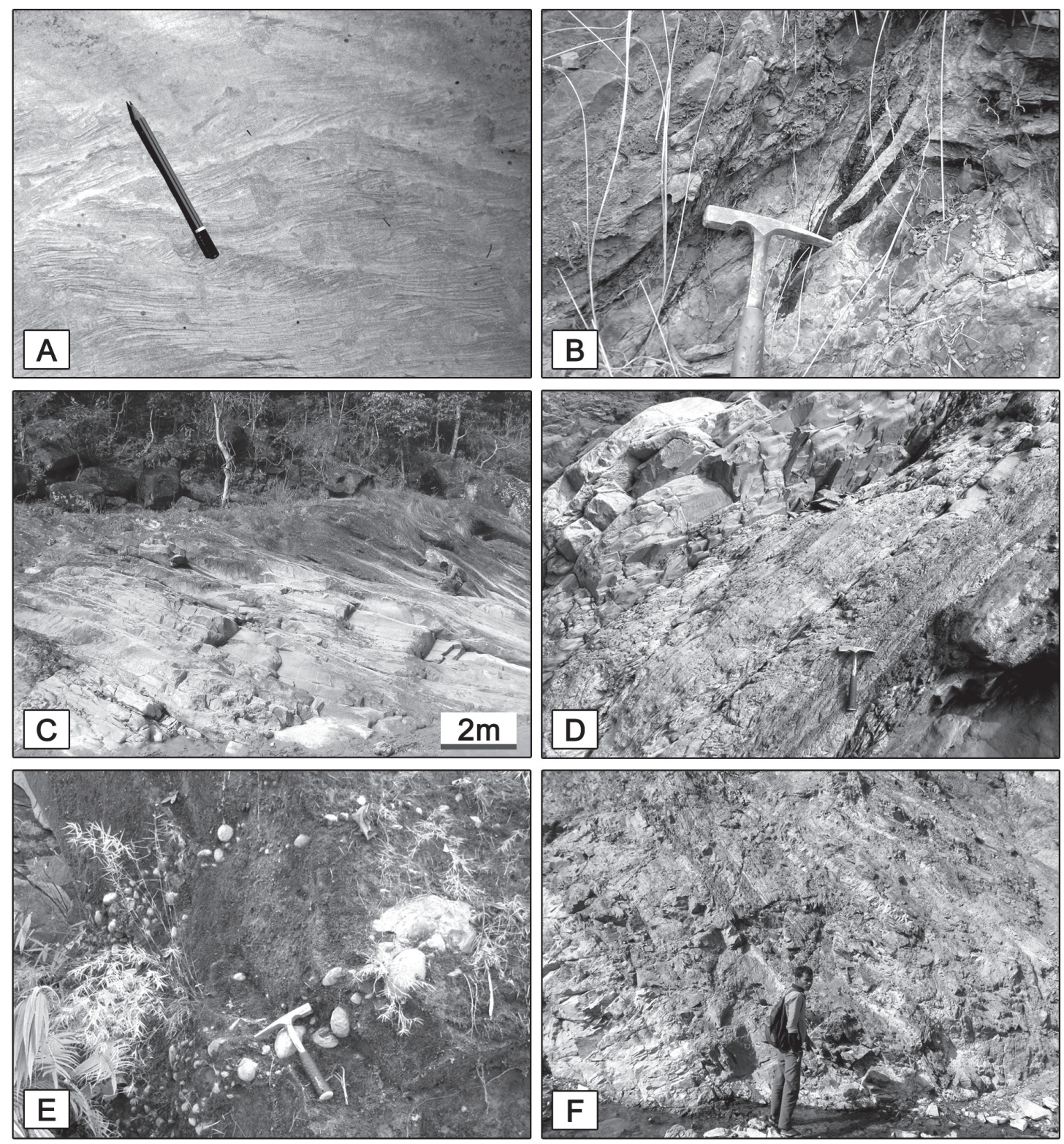

Fig. 6: Outcrop photographs of the Kala Formation. A) Ripple lamination in sandstone, B) Coal lens, C) Thick sandstone beds, D) Finely laminated greenish-grey mudstone, E) Quartzite pebble-cobble in sandstone and F) Fractured zone around the MDT (between the southern and central belt of the Siwalik Group). (A, B in the lower member. C, D in the middle member. E, in the upper member) 


\section{Upper member}

The upper member is well exposed around Sayal Village and the total thickness is about $400 \mathrm{~m}$. This member is characterized by thick- to very thick-bedded, fine- to very coarsegrained, greenish-grey (GLEY1 6/10GY) to grey (GLEY1 6/N, $5 Y$ 6/1) "salt and pepper" sandstones and pebbly sandstones interbedded with reddish-brown (5YR 4/3), greenish-grey (GLEY2 6/5BG) to black (GLEY1 2.5/N) mudstones (Fig. $4 G)$. In this member the proportion of sandstones is higher than mudstones (Fig. 5). Thickness of sandstone units ranges from 0.4 to $21 \mathrm{~m}$, whereas a mudstone units range from 0.1 to $3 \mathrm{~m}$. Fining upward succession is frequently observed in sandstone units. The lower part of the fining-upward succession consists of trough and planar cross-laminated sandstones with scattered pebbles which are followed by parallel laminated sandstones in the upper part. Gravel size tends to be larger and some cobble sized gravels also appear in the upper portion of this member (Fig. 6E). Pebbles and cobbles are mainly composed of quartzite and sub-rounded to rounded in shape. In the upper most portion of this member few bands of conglomerates are sandwiched between the sandstone beds. Thinly laminated mudstones are frequently observed than paleosols. In some mudstone units the lower part is massive and the upper part is finely laminated. The upper horizon of some mudstone units is composed of black (GLEY1 2.5/N) organic rich materials. Bioturbations, rhizoliths as well as concretion and nodules are less frequent in paleosols than those in other members. The maximum thickness of fining-upward succession is about 21 $\mathrm{m}$. The distribution of the upper member is punctuated by E-W extended Main Dun Thrust (MDT) (Fig. 6F).

\section{CORRELATION WITH MAGNETOSTRATIGRAPHIC DATA}

Ojha et al. (2000) analyzed the magnetostratigraphy from upper part of the Lower Siwalik to middle part of the Middle Siwalik in the area. They have shown two possible correlations with Cande and Kent (1995)'s general magnetostratigraphy [Figures 6 and 7 in Ojha et al. (2000)]. The age at the boundary between the Lower and Middle Siwaliks is $11.05 \mathrm{Ma}$ in both cases (i.e. near the base of the C5n). They state that the correlation in Figure 6 in Ojha et al. (2000) is the more convincing correlation: the Figure 6 of Ojha et al. (2000)'s correlation is also used in the present study. Following their correlation, the rock units were dated from 13.30 to $7.65 \mathrm{Ma}$ (Fig. 7).

Referring the base point $\left(28^{\circ} 54^{\prime} \mathrm{N} ; 80^{\circ} 40^{\prime} \mathrm{E}\right)$ of their study, the interval is equivalent to the portion from upper part of the middle member of the Jagati Formation up to the upper part of the middle member of the Kala Formation. Due to lack of detailed descriptions and lithological data of their study, tentative ages for boundaries of the middle and upper members of the Jagati Formation, and that of the lower and middle members of the Kala Formation are estimated on the basis of the thickness data. The measured thickness of the analyzed interval in Ojha et al. (2000) is slightly different with the thickness of the present study. The members' thickness were

\section{Present Study}

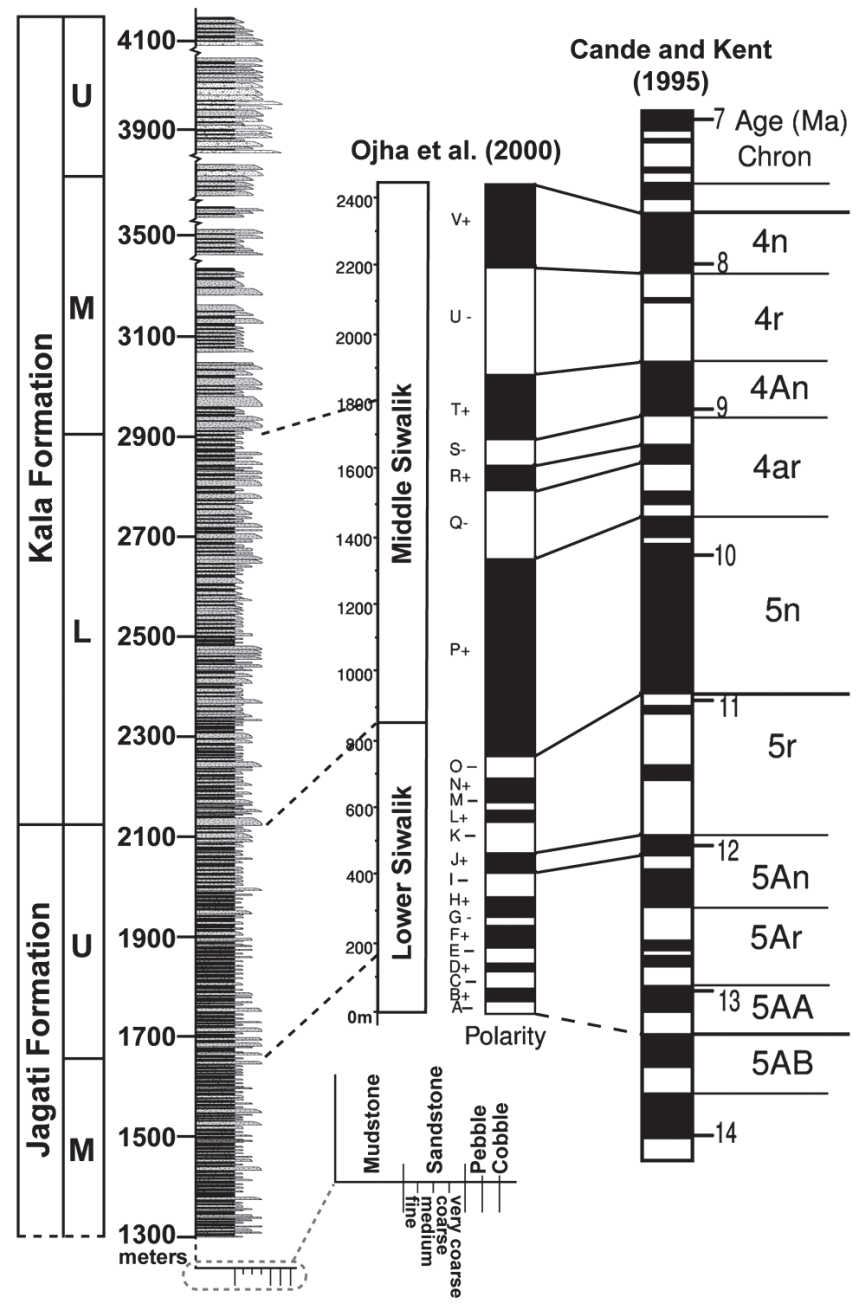

Fig. 7: Magnetostratigraphy and lithostratigraphy divisions of the Siwalik Group along the Khutia Khola section (modified from Ojha et al. 2000). The dark dashed lines indicate the tentative correlation.

recalculated by taking the aspect ratio between the members' thickness and total thickness of this study with measurements of Ojha et al. (2000) for the estimation of the age between the member boundaries. As the result, the boundary age of the middle and upper members of the Jagati Formation is estimated to be around 12.7 Ma and the lower and middle members of the Kala Formation is around 9.0 Ma.

\section{LITHOSTRATIGRAPHY AND COMPARISON}

This lithostratigraphic study corresponds with the previous studies of the Siwalik Group across the Nepal Himalaya. Our newly established lithostratigraphic units, the Jagati and Kala Formations permit regional correlation with other Siwalik successions in the Nepal Himalaya (Table 1). Lithologically, the Jagati and Kala Formations are correlatable with the Rapti and Amlekhganj Formations, respectively along the Hetauda-Bakiya Khola section in Central Nepal (Harrision et al. 1993, Sah et al. 1994, Ulak and Nakayama 1998), the 
Table 1: Classification of the Siwalik Group of the Nepal Himalaya and its correlation. The corresponding gery shades indicate the Upper, Middle and Lower Siwaliks. Numbers denote; 1) Hetauda-Bakiya Khola section, Central Nepal (Sah et al. 1994, Ulak and Nakayama 1998), 2) Tinau Khola section, Western Nepal (Tokuoka et al. 1986), 3) Surai Khola section, West Central Nepal (Dhital et al. 1995), 4) Karnali River section, Far Western Nepal (Sigdel et al. 2011) and 5) Khutia Khola section (present study), Far Western Nepal, dated boundaries are denoted in white box and tentative age is denoted comparing measured thickness of this study with age data (Ojha et al. 2000).

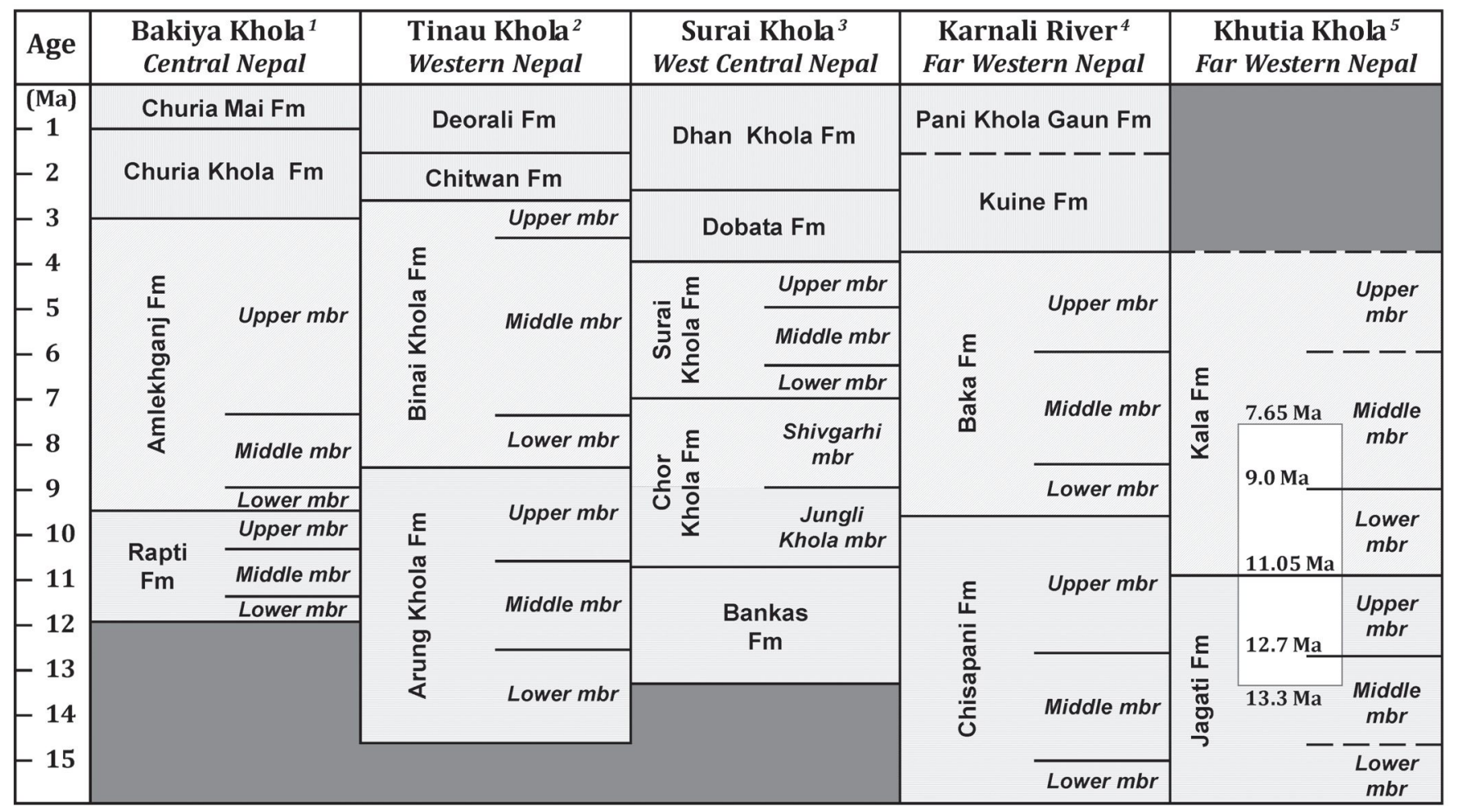

Arung Khola and Binai Khola Formations, respectively along the Arung Khola-Tinau Khola section in Western Nepal (Tokuoka et al. 1986, 1990; Gautam and Appel 1994), the Bankas Formation and the Jungli Khola member of the Chor Khola Formation, and the Shivgarhi member of the Chor Khola Formation and the Surai Khola Formation, respectively along the Surai Khola section in West Central Nepal (Corvinus and Nanda 1994, Appel and Rosler 1994, Dhital et al. 1995), the Chisapani and Baka Formations, respectively along the Karnali River section in Far Western Nepal (Sigdel et al. 2011).

\section{DEPOSITIONAL SETTING}

Previous studies on the fluvial system of the Siwalik Group reveals that the meandering river deposits characterize the lower part of the group, mostly the Lower Siwalik, and the sandy braided stream deposits (distal alluvial fan) makes up of the Middle Siwalik (e.g. Tinau Khola, Surai Khola, Bakiya Khola and Karnali River sections: Nakayama and Ulak 1999, Ulak and Nakayama 2001, Gautam and Fujiwara 2000, Hyughe et al. 2005, Dhital 2015). In general, the mudstone facies is more dominant in the Lower Siwalik than the Middle Siwaliks, grading upward into the sandstone dominated facies.

The Siwalik Group sediments of the Khutia Khola section is dominant in mudstones and very fine- to- finegrained sandstones, as well as thinner sandstone successions than other neighboring sections (Karnali River section to the east (Gautam and Fujiwara 2000, Hyughe et al. 2005, Sigdel et al. 2011) and Budar-Jogbudha area to the west, where the Lower Siwalik is represented by the equal proportion of sandstone and mudstone beds (Dhital 2015), and mudstone is also frequent even in the Kala Formation. This lithological differences from the neighboring area obviously indicate the fluvial facies of the Khutia Khola section is of a small river system and represent an interfluve setting of major streams.

\section{CONCLUSION}

The present study proposes new stratigraphic classification for the Siwalik Group around the Khutia Khola. The Jagati Formation is equivalent to the Lower Siwalik and is further subdivided into the lower, middle and upper members. The reddish-brown mudstone is dominant in this formation. The Kala Formation corresponds to the Middle Siwalik which is also subdivided into the lower, middle and upper members. This formation is characterized with "salt and pepper" sandstone along with the upper portion consists of pebbly sandstone. The Upper Siwalik is not exposed along the Khutia Khola section. The magnetostratigraphy and this newly defined lithostartigraphy are tentatively correlated with the reference of the measured thickness. This shows the age of the boundary between the Jagati and Kala Formations (LowerMiddle Siwaliks) is around 11.05 Ma as suggested in Ojha et al. 
(2000). The boundaries ages of the middle and upper members of the Jagati Formation is around 12.7 Ma and the lower and middle members of the Kala Formation is around 9.0 Ma. The dominance of the finer sediments and thinner sandstone units than the neighboring Siwalik successions indicate sediments of small river systems in the interfluve setting of major river systems.

\section{ACKNOWLEDGEMENTS}

We thank the Ministry of Education, Culture, Science and Technology of Japan for providing a MEXT scholarship for study to the first author. We are indebted to Dr. A. P. Gajurel, Dr. P. D. Ulak and Dr. D. P. Adhikari for their critical review and valuable suggestions on the manuscript. We also thank to P. Simkhada, L. Pandey and R.D. Joshi for their assistance during our fieldwork.

\section{REFERENCES}

Appel, E. and Rosler, W., 1994, Magnetic polarity stratigraphy of the Neogene Surai Khola section (Siwalik, SW Nepal). Himal. Geol., v. 15, pp. 63-68.

Auden, J. B., 1935, Traverses in the Himalaya. Records of the Geological Survey of India. v. 69, pp. 123-167.

Burbank, D. W., Beck, R. A. and Mulder, T., 1996, The Himalayan Foreland: Asian Tectonics. Cambridge Univ. Press, pp. 14-188.

Cande, S. C. and Kent, D. V., 1995, Revised calibration of the geomagnetic polarity timescale for the Late Cretaceous and Cenozoic. Jour. Geophys. Res., v. 100, pp. 6093 6095.

Corvinus, G. and Nanda, A. C., 1994, Stratigraphy and paleontology of the Siwalik group of Surai Khola and Rato Khola in Nepal. N. Jb. Geol. Palaont. Abh., v. 191, pp. 25-68.

Corvinus, G. and Rimal, L. N., 2001, Biostratigraphy and geology of the Neogene Siwalik Group of the Surai Khola and Rato Khola areas in Nepal. Palaeo,, v. 165, pp. 251-279.

DeCelles, P. G., Gehrels, G. E., Quade, J., Ojha, T. P., Kapp, P. A. and Upreti, B. N., 1998, Neogene foreland basin deposits, erosional unroofing, and the kinematic history of the Himalayan fold-thrust belt, western Nepal. Jour. Geol. Soc. Am. Bull., v. 110, pp. 2-21.

Dhital, M. R., 2015, Geology of the Nepal Himalaya. Springer International Publishing, Switzerland, 498 p.

Dhital, M. R., Gajurel, A. P., Pathak, D., Paudel, L. P. and Kizaki, K., 1995, Geology and structure of the Siwaliks and Lesser Himalaya in the Surai Khola-Bardanda area, Mid Western Nepal. Bull. Dept. Geol. Tribhuvan Univ., v. 4, pp. 1-70.

Gansser, A., 1964, Geology of the Himalayas. Interscience, London, $289 \mathrm{p}$.
Gautam, P. and Appel, E., 1994, Magnetic polarity stratigraphy of the Siwalik Group sediments of the Tinau Khola section in west central Nepal, revisited. Geophys. Jour. Int., v. 117, pp 223-234.

Gautam, P. and Fujiwara, Y., 2000, Magnetic polarity stratigraphy of Siwalik Group sediments of the Karnali River section in western Nepal. Geophys. Jour. Intern., v. 142, pp. 812-824.

Glennie, K. W. and Ziegler, M. A., 1964, The Siwalik Formations of Nepal. Int.. Geol. Congr., 22, Delhi, v. 25, pp. 82-95.

Hagen, T., 1969, Report on the Geological Survey of Nepal: Preliminary Reconnaissance. Denkschr. Naturw. Ges. v. $86,185 \mathrm{p}$.

Harrison, T.M., Copeland, P., Hall, S.A., Quade, J., Burner, S., Ojha, T.P. and Kidd, W.S.F., 1993, Isotopic preservation of Himalayan/Tibetan uplift, denudation and climatic histories in two molasses deposits. Jour. Geol., v. 101, pp. 157-175.

Huyghe, P., Mugnier, J. L., Gajurel, A. P, and Decaillau, B., 2005. Tectonic and climatic control of the changes in the sedimentary record of the Karnali river section (Siwaliks of western Nepal). The Island Arc, v. 14, pp. 311-327.

Medlicott, H. B., 1875, Note on the geology of Nepal. Rec. Geol. Surv. India., v. 8, pp. 93-101.

Munsell Color., 2000, Munsell Soil Color Charts. Gretag Macbeth, New Windsor.

Nakayama, K. and Ulak, P. D., 1999, Evolution of fluvial style in the Siwalik Group in the foothills of the Nepal Himalaya. Sediment. Geol., v. 125, pp. 205-224.

Ojha, T. P., Butler R. F., Quade, J., DeCelles, P. G., Richards, D. and Upreti, B. N., 2000, Magnetic polarity stratigraphy of the Neogene Siwalik Group at Khutia Khola, far western Nepal. Jour. Geol. Soc. Am. Bull., v. 112, pp. 424-434.

Piligram, G. E., 1913, The correlation of the Siwaliks with mammal horizons of Europe. Rec. Geol. Sur. In., v. 43 (4), pp. 264-326.

Prakash, B., Sharma, R. P. and Roy, A. K., 1980, The Siwalik Group (molasses) sediments shed by collision of continental plates. Sediment. Geol., v. 25, pp. 127-159.

Quade J., Cater, J. M. L, Ojha, T. P., Adam J. and Harrison, T. M. 1995, Late Miocene environmental change in Nepal and the northern Indian subcontinent: Stable isotope evidence form paleosols. Jour. Geol. Soc. Am. Bull., v. 107, pp. 1381-1297.

Robinson, D. M., DeCelles, P. G. and Copeland, P., 2006, Tectonic evolution of the Himalaya thrust belt in western Nepal: Implication for channel flow models. Jour. Geol. Soc. Am. Bull., v. 118, pp. 868-885. 
Rosler, W., Metzler, W. and Appel, E., 1997, Neogene magnetic polarity stratigraphy of some fluviatile Siwalik sections, Nepal. Geophys. Jour. Int., v. 130, pp. 89-111.

Sah, R. B., Ulak, P. D., Gajurel, A. P. and Rimal, L. N., 1994, Lithostratigraphy of the Siwalik sediments of the Amlekhganj-Hetauda area, sub-Himalaya of Nepal. Him. Geol., v. 15, pp. 37-48.

Sharma, C. K., 1973, Geology of Nepal. Education Enterprises, Kathmandu. 164 p.

Sharma, S. R., Subedi, D. N., KC, S. B., Khanal, R. P., Tripathi, G. N., 2007, Geological Map of Petroleum Exploration Block-1, Dhangadi, Far Western Nepal (Scale: 1:250,000). Petroleum Exploration Promotion Project, Department of Mines and Geology, Kathmandu, Nepal.

Sigdel, A., Sakai, T., Ulak, P. D., Gajurel, A. P. and Upreti, B. N., 2011, Lithostratigraphy of the Siwalik Group, Karnali River section, far-west Nepal Himalaya. Jour. Nepal Geol. Soc., v. 43, pp. 83-101.

Tokuoka, T., Takayasu, K., Yoshida, M. and Hisatomi, K., 1986, The Churia (Siwalik) Group of the Arung Khola area, West Central Nepal. Mem. Fac. Sci. Shimane Univ., v. 20, pp. 135-210.

Tokuoka, T., Takeda, S., Yoshida, M. and Upreti, B. N., 1988, The Churia (Siwalik) Group in the Western Part of the Arung Khola area, west central Nepal. Mem. Fac. Sci. Shimane Univ., v. 22, pp. 131-140.
Tokuoka, T., Takayasu, K., Hisatomi, K., Yamasaki, H., Tanaka, S. Konomatsu, M., Sah, R.B. and Rai, S.M., 1990, Stratigraphy and Geologic Structures of the Churia (Siwalik) Group in the Tinau Khola-Binai Khola Area, West Central Nepal. Mem. Fac. Sci. Shimane Univ., v. 24, pp. 71-88.

Ulak, P. D. and Nakayama, K., 1998, Lithostratigraphy and evolution of the fluvial style in the Siwalik Group in the Hetauda-Bakiya Khola area, Central Nepal. Bull. Dep. Geol., Tribhuvan Univ., v. 6, pp. 1-14.

Ulak, P. D. and Nakayama, K., 2001, Neogene fluvial systems in the Siwalik Group along the Tinau Khola section, west central Nepal Himalaya. Jour. Nepal Geol. Soc., v. 25, (Sp. Issue), pp. 111-122.

Upreti, B. N., 1999, An overview of the stratigraphy and tectonics of the Nepal Himalaya. Jour. Asian Earth Sci., v. 17 , pp. 577-606.

Upreti, B. N. and Le Fort, P., 1999, Lesser Himalayan crystalline nappes of Nepal: Problems of their origin, in Macfarlane, A., Sorkhabi, R. B. and Quade, J. (eds.), Himalaya and Tibet: Mountain Roots to Mountain Tops. Geol. Soc. Am., v. 328 (Sp. Paper), pp. 225-238.

Wadia, D. N., 1957, Geology of India. Macmillan Pub., London, $536 \mathrm{p}$.

Yoshida, M. and Arita, K., 1982, On the Siwaliks observed along some routes in Central Nepal. Jour. Nepal Geol. Soc., v. 2, (Sp. Issue), pp. 51-58. 